\title{
Arab Spring vs. Zero Problems Policy \\ Impact of the Arab Spring on the Trade Expansion of Turkey
}

\author{
Engin Sorhun, $\mathrm{PhD}^{\mathrm{a}}$ \\ ${ }^{a}$ Istanbul Dogus Univesity, Faculty of Business and Administrative Sciences, 34722, Istanbul, Turkey \\ University of Strasbourg, Bureau de l'Economie Théorique et Appliquée, 67085, Strasbourg, France
}

\begin{abstract}
Although Turkey has historically concentrated its trade with the European Union (EU) it has diversified its trade markets with the neighbouring regions and different group of countries during the last decade. Among them, Arab countries have come into prominence. Especially, following the "zero problems with neighbours" policy (ZPN), pursued by Turkey since 2002, the trade volume with the Middle Eastern neighbours has increased faster than that with its traditional partners. Nevertheless so called "Arab Spring" has started to manifest its effects on this trend. It deteriorates not only the economies of the concerned countries but also Turkey's trade expansion. This paper aims: (i) to test through a gravity model the positive impacts of the ZPN policy and the negative impact of the Arab Spring on the trade expansion with the Spring Countries; and (ii) to reveal the positive impact of the policy change and the negative impact of the uprising movements on the realization of trade potential by Turkey in the Spring Countries.
\end{abstract}

Keywords: Bilateral Trade Flows, Zero Problems with Neighbours, Arab Spring, Turkey, Egypt, Tunisia, Libya, Syria

\section{(C) 2013 Published by SSBFNET}

\section{Introduction}

For long most of the research literature on Arab countries have dealt with the political issues. In the last decade there has been a considerable interest in the economies of the Middle East, especially Arab ones. However, the decaderesearches in the trade literature seem to be focused on Intra-Arab trade and regional integration (Al-Atrash and Yousef, 2000; Nugent, 2002; Nugent and Yousef, 2005), impacts of regional trade agreements (Ghoneim, 2003; McQueen, 2002; Francois et al., 2005; Denis, 2006). Recent papers give the importance to the so called "Arab Spring" and the impact of uprising movements and transformation on the middle and long term economic perspective of the

\footnotetext{
${ }^{\text {a }}$ Corresponding author.
} 
Arab Spring countries (Malik and Awadallah, 2011; Breisinger et al, 2011; Hakimian, 2011; Bauer and Schiller, 2012). Nevertheless, despite a large number of papers on such matters, there is still a lack of research analysing the trade structure between Arab countries and Turkey.

Turkey that historically concentrated its trade flows mainly with the European countries has diversified its export and import markets during the last decade. The Middle East and the North Africa, particularly, the Arab countries have come into prominence in the trade market of Turkey. Although European partners keep their relative weight on the Turkish trade market, the diversification in trade orientation due to the policy preference, implemented since 2002, has allowed Turkey to expand its export market in the Arab world.

Nevertheless the Arab Spring has been jeopardizing Turkish export market and this has a possibility of breaking down the recent development in trade flows. Moreover politic instability, risk of internal war, worsened economic situation, slowing reform process resulting from awakening movements seem to be the signs that the impacts of the Arab Spring on trade flows can last longer.

This paper analyses Turkey's trade orientation toward the Arab World, especially the Spring countries in framework of policy change and recent developments and aims to fill a part of the lack in the concerned research literature.

The rest o of the paper is organized as follows: Section 2 summarizes the zero problems with neighbours policy and the changing orientation in the pattern of trade flows of Turkey; Section 3 discusses the specification of the model; Section 4 presents the main results of the estimated model; Section 5 deals with the realized magnitude of the potential trade of Turkey with Spring countries; and finally section 6 presents the results.

\section{Trade Pattern of Turkey before and after "Zero Problems with Neighbours" Policy}

The European Union (EU) has always been the main trade partner of Turkey even before it was not an economic integration entity ${ }^{\mathrm{b}}$. Despite geographically further, Turkey has concentrated more trade flows with its EU partners than its neighbouring countries. There are some plausible reasons (economic as well as politic) to explain this situation:

- $\quad$ The industrialisation gap between two sides has led Turkey to import final goods from the EU more than from any other region; and to export raw materials and intermediary goods to the EU more than to any other region.

- $\quad$ The lack of production complementarity and the relative similarity of resource endowments (except energy commodities) between Turkey and its neighbour countries argues against intraregional trade since the comparative advantage among countries in question is mainly in the same products. The lack of diversified products in manufactures has limited the trade opportunities.

\footnotetext{
${ }^{\mathrm{b}}$ In my paper the EU is considered rather as a geographical entity and a region.
} 
- Joining the European Customs Union in 1996 and EU membership process helped both Turkey and the EU members to enter each other's markets.

- $\quad$ One of the reasons that is non-economic results from the foreign policy: since its foundation Turkish Republic acted on the international scene as a family-member of the western world. This political posture is clearly seen especially in the reaction when it immediately applied for membership to the international organisations. Being a member of such western origin organisations contributed to improvement in trade with western countries (particularly the EU).

- As a member of the NATO, Turkey reduced its relation with the socialist countries to minimum during cold war. Surrounded by Eastern Bloc countries (the URSS, Bulgaria, Romania), or by Middle Eastern countries with the Arab Socialist Ba'ath Regime (Iraq, Syria), Turkey was almost an outpost of the NATO in a region with high tension. This policy preference kept Turkey far from its neighbours even after the dispersion of the Soviet Bloc and the weakening of Ba'ath Regimes following the Gulf War I.

As from the end of the cold war some political changes occurred in Turkey's relation with its "ex-enemies" which were once part of Soviet Bloc or the Ex-URSS but not with its close or far Arab neighbours. However though it tried to develop relations with Arab world as a trade partner at the beginning of the 1990's it did not last long. Trade volume with Arab countries remained below its potential level until the implementation of the "Zero problems with neighbours" (ZPN) policy since 2002.

Essentially not a new concept for Turkey, the ZPN policy is not put into practice in 2002 but dated back to the 1930's. Before the World War II, Mr. Kemal Atatürk, founder of the Republic, established the Balkan Pact with Greece, Romania, Yugoslavia in 1934, and the Sadabat Pact with Iran, Iraq and Afghanistan in 1937. In that period Turkish state maintained distanced but balanced-relationship with Moscow and Arab capitals while trying to establish closer ties with the western world. That multidirectional policy coerciblely blurred after the redistribution of the cards at the end of the World War II. Formation of the new blocks, political polarisation, regime changes, and regional integration that happened around Turkey had an impact through policy preference on the trade orientation of the country.

However, the end of the cold war that made emerge many opportunities for many countries while redistributing the cards permitted Turkey to revise its policy towards regions around itself, especially countries with Muslim population. One of the Turkish scholars who tried to develop a new foreign policy approach for Turkey is Mr. Ahmed Davutoğlu. Specialized in the pre-cold war and post-cold war international systems he based his analysis on the historical and cultural legacy inherited by Turkey and the opportunities and responsibilities of geostrategic location. In his book ("Strategic Depth: The International Position of Turkey" in English) which he wrote down before becoming the foreign advisor to Prime Minister after the election in $2002 \mathrm{Mr}$. Davutoğlu emphasized the significance of the diverse regional composition of Turkey, which gives Turkey the ability of maneuver in several regions simultaneously. For him "a central country with such an optimal geographic location cannot define itself in a defensive manner. It should 
be seen neither as a bridge country which only connects two points, nor a frontier country, nor indeed as an ordinary country, which sits at the edge of the Muslim world or the West." Davutoglu also underlines the main principles of this new foreign policy approach. According to him, these principles include: i) a balance between security and democracy; ii) zero problems policy towards Turkey's neighbours; iii) developing relations with neighbouring regions and beyond; iv) a multi-dimensional foreign policy; and v) "rhythmic diplomacy." with Muslim population.

Mr. Davutoğlu found the occasion of putting in practice his theoretical approach under the rule of the AKP governments, elected three times since 2002, when served as chief adviser and minister of foreign affairs. Before analysing the effect of the ZPN policy on trade flows it is useful to look at what he understands by "neighbourhood" and "zero problems with neighbours":

First, for him neighbouring countries are not necessarily the ones sharing common border with Turkey but the ones located in the same geographical region. As Turkey is found in a crossroads, it has historical and cultural ties with Balkans, Black Sea Region, Caucuses and Central Asia, Middle East and North Africa, East Mediterranean at the same time. Thus, in Mr. Davutoğlu's jargon "neighbours" means "neighbouring regions".

Second, most of the countries in the neighbouring regions are ruled by dictatorships or authoritarian regimes where the powerful central elites are suspicious and mistrustful about external efforts for developing cooperation. As a result, the ZPN policy must be used as a diplomatic tool to bypass the obstacles imposed by central elite and authoritarian regimes ${ }^{c}$. As for economic connections, this policy helps opening the doors to Turkish business circles in expending export market, developing commercial linkage, taking a share in neighbours' public market. Mr. Davutoğlu expressed this point of view in his book: "Particularly in our region, where authoritarian regimes are the norm, improving transport possibilities, extending cross-border trade, increasing cultural exchange programs, and facilitating labour and capital movement [...] will help overcome problems stemming from the role of the central elites." (Davutoğlu, 2001).

The implementation of the ZPN policy manifests itself concretely when increasing number of intergovernmental visits and ratified bilateral agreements, abolishing visa, liberalizing border trade and capital movement, incitement for foreign investment among neighbouring countries, particularly those in the Middle Eastern region.

Graphic 1 shows the speed progress in trade flows between Turkey and Arab countries after the ZPN policy, put into practice since 2002. Before that year trade volume seems to stay at a stable modest level and trade balance seems rather balanced. It is as from 2002 that trade balance started to turn against Arab countries. Turkey's export volume

\footnotetext{
${ }^{c}$ On the one hand, it seems that the ZPN Policy essentially aims to alleviating the effect of the obstacles that the central elites of the authoritarian regimes have put, not just to establish close relationship with these authoritarian regimes. This posture was explicitly observed when Turkish government actively reacted and declared its support to popular movements opposing these authoritarian regimes in Tunisia, Egypt, Libya, Yemen, and recently Syria by jeopardizing its new export market and investments in these countries. But on the other hand, it is criticized for the fact that It did not show a similar reaction when it is about the riots in the Arab States of the Gulf.
} 
toward Arab countries in 2012 reaches at a level four times bigger than that in 2002. If the value of Turkish exports to Arab countries grew at the same rhythm as in the period 1996-2003 it might be 5 times less than the average actual value in the period 2003-2012. Otherwise, if the share of exports to Arab countries in total exports of Turkey remained stable at the average level of the period 1996-2002 the value of the exports to these countries might be 6 times less than the average actual value in the period 2002-2012. Turkey has tripled its total export volume and has quadrupled its total import volume with the rest of the world since 2002 (Table 1). The main reflection of the ZPN policy on the trade policy is that Turkey has diversified its export markets especially with the members of the Organisation Islamic Cooperation (OIC) of which most of the members are Arab countries. Market diversification alleviated the dependence of Turkey on European export market, and made it less fragile vis-à-vis the effect of the global crisis that reduced export demand in Europe.

However the EU is still the main trade market even after the ZPN policy. Export toward the EU countries and imports from them have increased in volume but not in share. The EU export share in total exports of Turkey decreased on average by $\% 6$ since 2003 while the EU import share in total imports of Turkey is found \%12 low under the habitual level. Nevertheless the decrease in import share is not complemented by imports from neighbouring regions but emerging countries like China, Russia, and India. Turkey has also diversified its import markets but not with the OIC countries. Following the years when the ZPN policy is implemented the OIC share in total exports of Turkey has increased on average $\% 8$ while the OIC share in total imports remained stable. One of the probable reasons of that situation is the lack of production complementarity ${ }^{\mathrm{d}}$ (out of energy commodities).

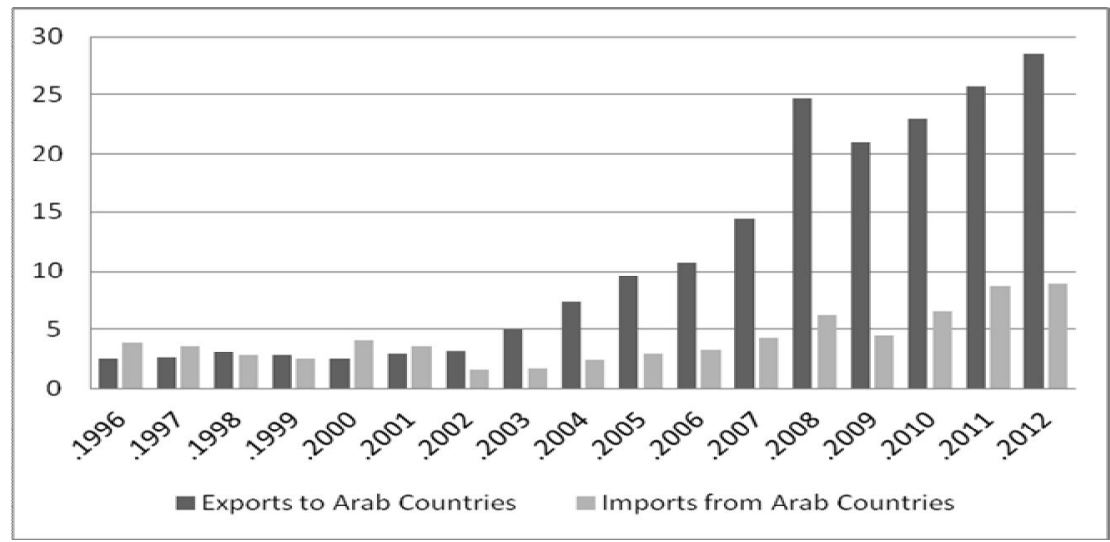

Source: Turkish Statistical Institute (2013)

Graph 1: Trade Flows between Turkey and Arab Countries (billion USD)

\footnotetext{
${ }^{\mathrm{d}}$ It can be expected that Turkey has a differentiated goods based manufacturing market for exporting toward the OIC counties while they lack production complementarity for exporting toward Turkey.
} 
Nevertheless Turkey's imports from Arab countries have risen just modestly since 2002. Trade balance has moved in favour of Turkey, not Arab countries, since 2002, that is to say, the new foreign policy begun to be put in practice. But the rise in exports regressed after the year 2008 when global economic crisis started to show its negative effects.

Table 1: Trade Orientation of Turkey

\begin{tabular}{|c|c|c|c|c|c|c|}
\hline \multirow{2}{*}{ Periods } & \multicolumn{2}{|c|}{ Average Trade Flows of Turkey } & \multicolumn{2}{c|}{ EU Share in Total Trade } & \multicolumn{2}{c|}{ OIC Share in Total Trade } \\
\cline { 2 - 7 } & Exports & Imports & In Exports & In Imports & In Exports & In Imports \\
\hline $1996-2003$ & $\$ 30,7$ bil. & $\$ 49,5$ bil. & $\% 56$ & $\% 52$ & $\% 15$ & $\% 10$ \\
\hline $2003-2012$ & $\$ 103,4$ bil. & $\$ 165,5$ bil. & $\% 50$ & $\% 40$ & $\% 23$ & $\% 10$ \\
\hline
\end{tabular}

Source: Turkish Statistical Institute (2013)

If we look at the composition of traded goods between Turkey and the OIC countries, or only Arab countries, we observe that Turkey exports final goods to and imports raw materials and energy commodities from them. Raw materials and energy commodities are the only goods for the OIC countries leading to production complementarity. It makes them advantageous vis-à-vis Turkey in trade balance.

Parallel to the rise in exports toward the other Arab countries, exports to the Spring countries (Egypt, Libya, Tunisia, Syria) ${ }^{\mathrm{e}}$ have increased about six times between 2002 and 2012. Even after the global economic crises that showed its effects from the end of 2008 increasing trend in exports had continued until the riots started in the Arab countries in turn $^{\mathrm{f}}$

Establishing close ties, developing temperate relations, and cooperation attempts with the Arab countries made the period 2002-2009 a spring time for Turkey as far as expanding trade surplus is concerned. But the seasons changed the place! Turkey's export market has shrunk by $\% 16$ since uprising movements started and shifted from one country to another in the Arab world. Narrowing in export demand, spread risk of uprising into other neighbouring countries, civil war danger, and political uncertainty turned the "spring" to a fall for Turkey. There are two main reasons for this: (i) Turkish government has supported uprising movements against authoritarian regimes in the Spring countries since the beginning by interpreting the word "neighbours" in "zero problems with neighbours" as "people" rather than "regimes". (ii) Even worse, deteriorating economic situation due to political instability has a negative impact on the medium and long-term perspective of national income and demand.

\footnotetext{
${ }^{\mathrm{e}}$ Of course spring countries are not limited to these four ones. However, the lack of data is the main reason for confining the analysis with these four countries.

${ }^{\mathrm{f}}$ Experts have long emphasized that persistent food security, slow progress in economic diversification, unemployment, social inequalities, and demographic structure are the major reasons for riots. In fact, these problems repeatedly happened in the past, too. But what makes this time different is the role of social media.
} 


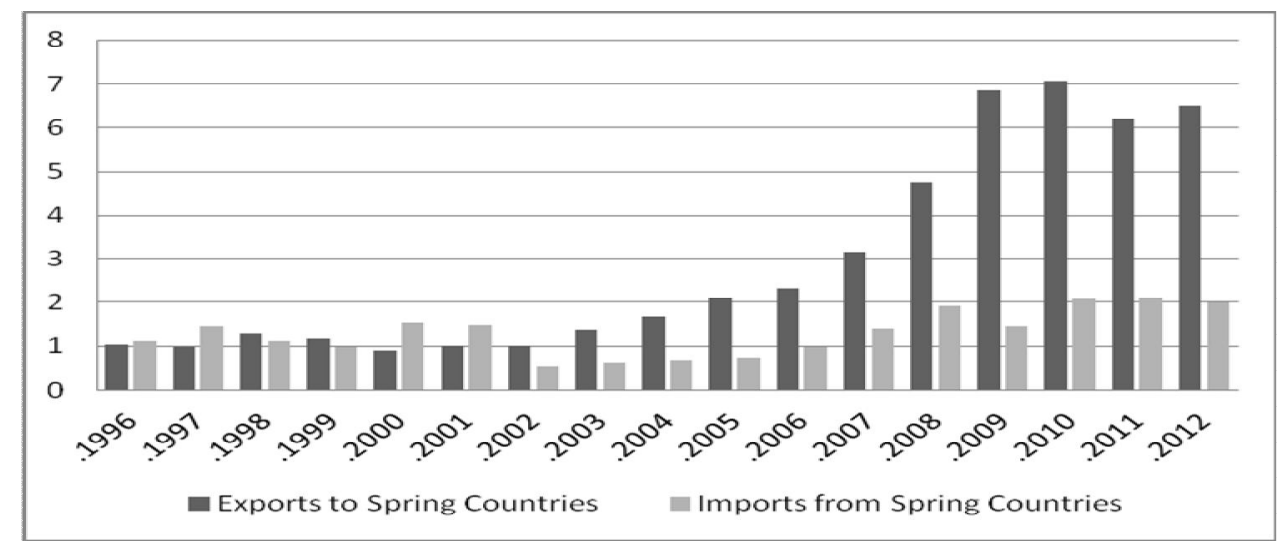

Source: Turkish Statistical Institute (2013)

Graph 2: Trade Flows between Turkey and the Spring Countries (billion USD)

In the next sections I will deal with how efficiently the ZPN policy has worked in realising the potential trade with the spring countries and how the Arab spring will influence trade flows between Turkey and the Spring countries through an estimation model.

\section{Spesification of the Model}

The gravity model has been the more used econometric approach to analyse trade flows since early 1960 's. The general idea behind it comes from the gravity theory in physic, from which it also derives its name. In its original version, the attraction between two physical entities with a larger mass is higher than between two physical entities with a smaller mass. However, the farther they are away from each other the weaker is such attraction.

The gravity model has proved to be popular and empirically successful in explaining bilateral trade flows. Timbergen (1962) applied it to international trade, explicitly including the geographical dimension in his analysis and treating countries as entities having a physical location ${ }^{\mathrm{g}}$. Examples of empirical studies framed on the gravity equation include the evaluation of trade protection (Harrigan, 1993), regional trade agreements (Frankel et all, 1995; Frankel, 1997), "border-effects" influencing the patterns of intra-national and international trade (McCallum, 1995; Anderson and van Wincoop, 2001), geography and trade linkage (Hummels, 2001a, 2001b; Redding and Venables, 2004; Limao and Venables, 2001; Brun et al., 2002).

In the gravity approach, trade is estimated as a function of various trade determinants for a reference group of countries. The fundamental variables used to estimate gravity equation: (1) Income parameters of exporting and

\footnotetext{
g In the context of the gravity model, the "physical entities" are the exporting and importing countries, and the "masses" are their economical sizes. The larger the economies of the involved countries are, the larger the trade among them is. However, distance causes a resistance to trade, because of transport costs and delivery lags, among other things such as tariffs barriers, border controls, quantitative restrictions and exchange rate volatility.
} 
importing country (GDP, GNP, GDP or GNP per head, purchasing power parity ect.), (2) transport and transaction cost (generally "distance" term) and other variables representing policy and cultural effect on trade. It is expected that higher level of income leads to trade rise. Briefly, the gravity equation provides an econometric analysis for the empirical relationship, among trade, income, distance, and several dummy variables.

I use a standard gravity model to examine whether the ZPN policy has contributed to realization of potential trade with the Spring countries and the hypothesis of whether Arab Spring has negative impact on expanding trade flows of Turkey.

The model predicts that the trade between two countries depends on their size, each country's income, and distance between them. That is:

$\mathrm{T}_{\mathrm{ij}}=\beta_{0} \mathrm{Y}_{\mathrm{i}}{ }^{\beta 1} \mathrm{Y}_{\mathrm{j}}{ }^{\beta 2}$ Dist $_{\mathrm{ij}}{ }^{\beta 3}$

Where $T_{i j}$ is the value of trade (exports, imports or total trade) between country $i$ and $j$; $Y_{i}$ and $Y_{j}$ are the levels of their GDP; and Dist $t_{i j}$ the geographical distance between the two countries. It is expected that trade is positively affected by economic size $\left(\beta_{1}, \beta_{2} \geq 0\right)$ and negatively related to distance $\left(\beta_{3} \leq 0\right)$.

I have made three spesificaitons on the model: (i) I separate the value of exports and the value of imports as explained variables; (ii) I augmented the simple model with dummy variables to capture the effect of the ZPN policy and the Arab Spring on trade; and (iii) I have written the model adaptable into time-series data settings to capture stationary process $^{\mathrm{h}}$. With these specifications the gravity model takes the following form:

$\ln X_{\mathrm{ijt}}=\beta_{0} \mathrm{CONS}+\beta_{1} \operatorname{lnGDP}_{\mathrm{it}}+\beta_{2} \operatorname{lnGDP}_{\mathrm{jt}}+\beta_{3} \ln \operatorname{WDIST}_{\mathrm{ijt}}+\beta_{4} \mathrm{ZPN}_{\mathrm{t}}+\beta_{5} \mathrm{SPRING}_{\mathrm{t}}+\varepsilon$

$\ln \mathrm{M}_{\mathrm{ijt}}=\beta_{0} \mathrm{CONS}+\beta_{1} \operatorname{lnGDP}_{\mathrm{it}}+\beta_{2} \operatorname{lnGDP} \mathrm{ln}_{\mathrm{jt}}+\beta_{3} \ln _{\mathrm{WDIST}} \mathrm{ijt}+\beta_{4} \mathrm{ZPN}_{\mathrm{t}}+\beta_{5} \mathrm{SPRING}_{\mathrm{t}}+\varepsilon$

Where:

- $C O N S$ is the constant term

- $G D P_{i t}$ and $G D P_{j t}$ are the Turkey's GDP and its partner country's GDP at time t, respectively.

- $W D I S T_{i j t}$ is GDP weighted distance between Turkey and its partner country at time t.

\footnotetext{
${ }^{\mathrm{h}}$ In Gravity type models time-fixed regressors like geographical or cultural distance, language and institutional (dummy) variables are widely used to analyse the impact of trade costs on bilateral trade. Panel data settings help avoid the inconsistency problem due to a correlation of the time-fixed regressors with the combined error term in the model. It is the major reason for using gravity models based on panel data in the literature on trade. Nevertheless, since estimated gravity models based on panel data are often static they only allow for contemporaneous effects of the regressors on trade while ignoring dynamics effects (De Grauwe and Skudelny, 2000). In multi-country case cross-sectional time series data set, in bi-country case time-series data set allows to explain dynamic effects while estimating gravity model.
}

${ }^{\mathrm{i}} \operatorname{WDIST}_{\mathrm{ijt}}=\left[\mathrm{GDP}_{\mathrm{it}}-\mathrm{GDP}_{\mathrm{jt}} \mathrm{t} /\left[\mathrm{GDP}_{\mathrm{it}}+\mathrm{GDP}_{\mathrm{jt}}\right]\right.$ 
- $Z P N_{t}$ is the dummy, equal 1 for the quarters from QI-2003 to QII-2013, and 0 otherwise.

- $S P R I N G_{t}$ is the dummy, equal 1 for the quarters after uprising started in each country, and 0 otherwise.

- $\varepsilon$ is the error term.

\section{Emprical Results}

The empirical results presented below are based on these estimation models (equation 2 and equation 3). As estimation method I use OLS that has become the standard technique in the literature. The models are estimated for four Spring countries (Egypt, Libya, Tunisia, Syria). All data are for quarterly period from QI-1996 to QII-2013. The imports and exports data are taken from the Trade Statistics of the Turkish Statistical Institute. And income data are obtained from the World Bank.

The results of the regressions are presented in the Table 2A and 2B. The values in brackets are $t$ values. The typical empirical success of the gravity specification is clearly manifested. All coefficients give the expected signs, plausible magnitudes and are statistically significant at 1 percent confidence level. For every regression the null hypothesis that the regressors have no impact on the regressand is rejected $\left(\mathrm{F}>\mathrm{F}_{\alpha=0,01}\right)$. At the bottom of each column are the number of observations and the value of $\mathrm{R}^{2}$. The later tells us that, after taking into account the number of regressors, the models explains 85-91 percent of the variation for export side and 82-89 percent of the variation for import side, respectively.

Country specific factors are omitted. The unit root test rejects the null hypothesis that all variables are non-stationary ${ }^{j}$. As expected the variables representing economic sizes of the countries have positive impact; and the distance variable has negative impact on trade flows. The magnitude of economic size of Turkey $\left(\mathrm{GDP}_{\mathrm{it}}\right)$ is more determining over both sides of trade than those of the partner countries. Income weighted distance (WDIST $\mathrm{ijt}_{\mathrm{ij}}$ ) that has a high negative sign in every case represents the resistance factor to expanding bilateral trade ${ }^{\mathrm{k}}$. However, since the constant terms have also negative sign for every country this indicates that there are other possible resisting factors.

The parameters of the dummy variables indicate the percentage change in the dependent variable due to the unit increase in the dummy (from ' 0 ' to ' 1 '). The ZPN policy has a positive impact on trade with the Spring countries. However the estimated coefficients of $Z_{\mathrm{PN}_{\mathrm{t}}}$ on the export side are more powerful than those on the import side. Moreover the impact of the ZPN got a stationary trend. The ZPN policy has contributed to the expanding exports by \%7-12 while it has contributed to the imports only by about \%1-2. The ZPN policy serves rather Turkey in expanding its export market than it serves its partners in expending their exports toward Turkey.

\footnotetext{
${ }^{\mathrm{j}}$ I tested the stationarity through Augmented Dickey-Fuller test: the null hypothesis is $\hat{\gamma}=0$ and the alternative hypothesis is $\gamma<0$. As the computed test statistic is less than the critical value the null hypothesis that a unit root is present is rejected.

${ }^{\mathrm{k}}$ The Linder Hypothesis tells us about international trade patters that intensity of bilateral trade between two economies depends on the similarity of their demand structures (incomes, preferences, factor endowments, specializations, product differentiations). This hypothesis allows us to say that Turkey and the Spring countries have different demand structures provoking the resistance to trade.
} 
Table 2A: Estimation Results for Export Side

\begin{tabular}{|c|c|c|c|c|}
\hline \multicolumn{5}{|c|}{ Dependent Variable: $\ln \mathrm{X}_{\mathrm{ijt}}$} \\
\hline Variables & Egypt & Libya & Tunisia & Syria \\
\hline CONS & $\begin{array}{l}-11,89154 \\
(-9,78521)\end{array}$ & $\begin{array}{c}-8,110216 \\
(-20,19547)\end{array}$ & $\begin{array}{l}-4,326471 \\
(-5,86497)\end{array}$ & $\begin{array}{c}-12,98647 \\
(-11,12008)\end{array}$ \\
\hline $\ln G D P_{i t}$ & $\begin{array}{c}1,22150 \\
(11,03694) \\
\end{array}$ & $\begin{array}{c}0,69615 \\
(8,11894) \\
\end{array}$ & $\begin{array}{c}1,12001 \\
(5,69321) \\
\end{array}$ & $\begin{array}{c}1,54592 \\
(6,69086) \\
\end{array}$ \\
\hline $\ln G D P_{j t}$ & $\begin{array}{l}0,541112 \\
(7,15514) \\
\end{array}$ & $\begin{array}{c}0,47336 \\
(10,13251) \\
\end{array}$ & $\begin{array}{c}0,54123 \\
(6,69321) \\
\end{array}$ & $\begin{array}{c}0,79154 \\
(7,12589) \\
\end{array}$ \\
\hline $\ln W D I S T_{i j t}$ & $\begin{array}{c}-0,36444 \\
(-8,79647)\end{array}$ & $\begin{array}{c}-0,42164 \\
(-9,86952)\end{array}$ & $\begin{array}{c}-0,34031 \\
(-9,02159)\end{array}$ & $\begin{array}{c}-0,26264 \\
(-8,19216)\end{array}$ \\
\hline$Z P N_{t}$ & $\begin{array}{c}0,09121 \\
(12,11411)\end{array}$ & $\begin{array}{c}0,07311 \\
(10,19203)\end{array}$ & $\begin{array}{c}0,11200 \\
(8,79624)\end{array}$ & $\begin{array}{c}0,12189 \\
(7,46931)\end{array}$ \\
\hline$S_{P R I N G_{t}}$ & $\begin{array}{c}-0,03264 \\
(-11,23610)\end{array}$ & $\begin{array}{c}-0,03120 \\
(-16,23697)\end{array}$ & $\begin{array}{c}-0,02130 \\
(-18,12340)\end{array}$ & $\begin{array}{c}-0,04452 \\
(-13,74291)\end{array}$ \\
\hline$R^{2}$ & 0,89 & 0,85 & 0,91 & 0,90 \\
\hline No. of Obs: & 70 & 70 & 70 & 70 \\
\hline
\end{tabular}

Table 2B: Estimation Results for Import Side

\begin{tabular}{|c|c|c|c|c|}
\hline \multicolumn{5}{|c|}{ Dependent Variable: $\operatorname{lnM}_{\mathrm{ijt}}$} \\
\hline Variables & Egypt & Libya & Tunisia & Syria \\
\hline CONS & $-8,22111$ & $-10,99215$ & $-6,12136$ & $-12,33654$ \\
& $(-4,56327)$ & $(5,29647)$ & $(5,96204)$ & $(-8,63249)$ \\
\hline $\operatorname{lnGDP}_{\mathrm{it}}$ & 0,61269 & 0,52964 & 0,48196 & 0,71269 \\
& $(8,86954)$ & $(11,16591)$ & $(8,76025)$ & $(6,33005)$ \\
\hline $\operatorname{lnGDP}_{\mathrm{jt}}$ & 0,32036 & 0,28962 & 0,31269 & $(6,40695$ \\
& $(9,12690)$ & $(9,78216)$ & $(9,26941)$ & $-0,21126$ \\
\hline $\operatorname{lnWDIST}_{\mathrm{ijt}}$ & $-0,29216$ & $-0,24264$ & $-0,25264$ & $(-14,11254)$ \\
\hline ZPN $_{\mathrm{t}}$ & $(-9,12697)$ & $(-11,00369)$ & $(-10,01975)$ & 0,01829 \\
& 0,02112 & 0,01921 & 0,00779 & $(15,69582)$ \\
\hline SPRING $_{\mathrm{t}}$ & $(13,11232)$ & $(15,18534)$ & $(13,86411)$ & $-0,05265$ \\
& $-0,04236$ & $-0,05693$ & $-0,04123$ & $(-9,66625)$ \\
\hline $\mathrm{R}^{2}$ & $(-13,36975)$ & $(-6,78546)$ & $(-9,96471)$ & 0,89 \\
\hline No. of Obs. & 0,82 & 0,87 & 0,84 & 70 \\
\hline
\end{tabular}

As for the impact of Arab Spring, although it has a short time period to manifest itself the impact of Arab Spring seems to get stationary progress. Even weak the coefficients of $\mathrm{SPRING}_{\mathrm{t}}$ variable constitute a resistance factor to trade expansion. Arab Spring movements have bigger negative impacts on Turkish export market than on imports from the Spring countries. Arab Spring has shrunk the Turkish export demand by about \%2-4 and the Turkish import demand by \%4-5. This support the hypothesis that the uprising movements in the Turkish trade partners have a negative impact on the bilateral trade flows. Since this negative impact becomes stationary one can expect the Arab Spring to deteriorate the advantageous status of Turkey vis-à-vis the Spring countries until pieces fall into places. Even authoritarian regimes falls political instability continues to threaten economic recovery. 


\section{Actual and Potential Trade (Actual Trade as a percentage of Potential Trade)}

In this section, we compare the trade volume predicted based on the basis of the estimated gravity coefficients with the actual trade volume for each Spring country and Turkey. The potential exports and imports are calculated for every quarter. And using actual data over computed values I develop an index applicable to exports and imports:

$\mathrm{A} / \mathrm{P}$ Exports $=\left[\left(\text { Actual Exports }_{\mathrm{ijt}}\right) /\left(\text { Potential Exports }_{\mathrm{ijt}}\right)\right]^{*} 100$ and

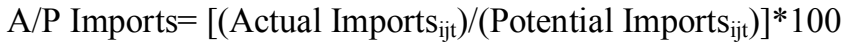

This index helps reveal the trade patterns of Turkey and Spring countries and measure to what extent Turkey and the partner countries realize their trade potential in each other's market. The results are presented in the graphics below:

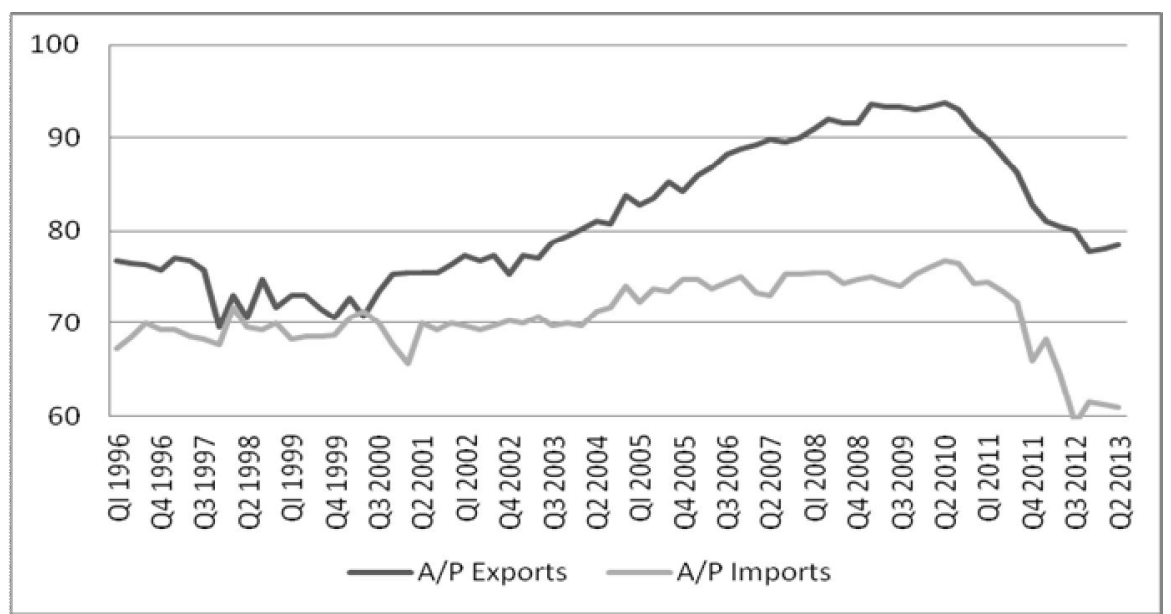

Graph 3: Overall A/P Index for the Spring Countries

As openly seen, Turkey and the Spring countries are under-trading. A/P indexes for exports and imports are found under $\% 100$. However, the gap between the export potential realization (A/P exports) and the import potential realization (A/P imports) is very small until 2003. It is the year 2003 that this gap enlarges in favour of Turkey. During the years when the ZPN is implemented the potential realization gap continue to grow. But from the last quarter of 2009 this trend seems to be broken. From QIV-2009 to QII-2013 A/P export index and A/P import index start to converge. The potential realization gap lessens in the quarters as Spring movement spreads out.

When we separately look at the concerned countries it appears that Turkey is under-exporting to and under-importing from all Spring countries. The index of projected Turkish exports over actual exports varies between $\% 75$ and $\% 85$ and the index of projected Turkish imports over actual imports varies between $\% 60$ and $\% 75$. That means that there is still a room for Turkey and its trade partners in terms of trade potential. Moreover this room is larger for the Spring countries than for Turkey. Because Turkish export level has gotten closer to its natural level while the Spring countries' export levels are very far from their natural levels. Thus potential gain from trading to Turkish market is considerably larger for these economies. 


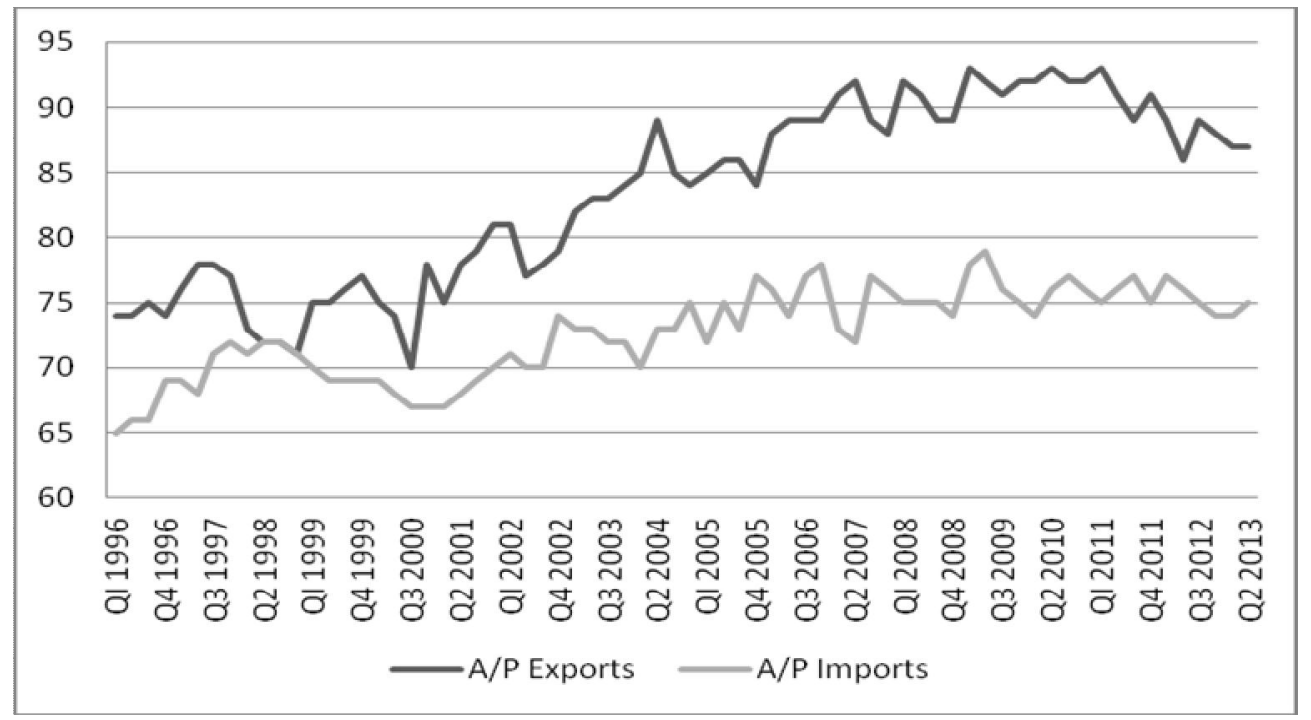

Graph 4: A/P Index for Egypt

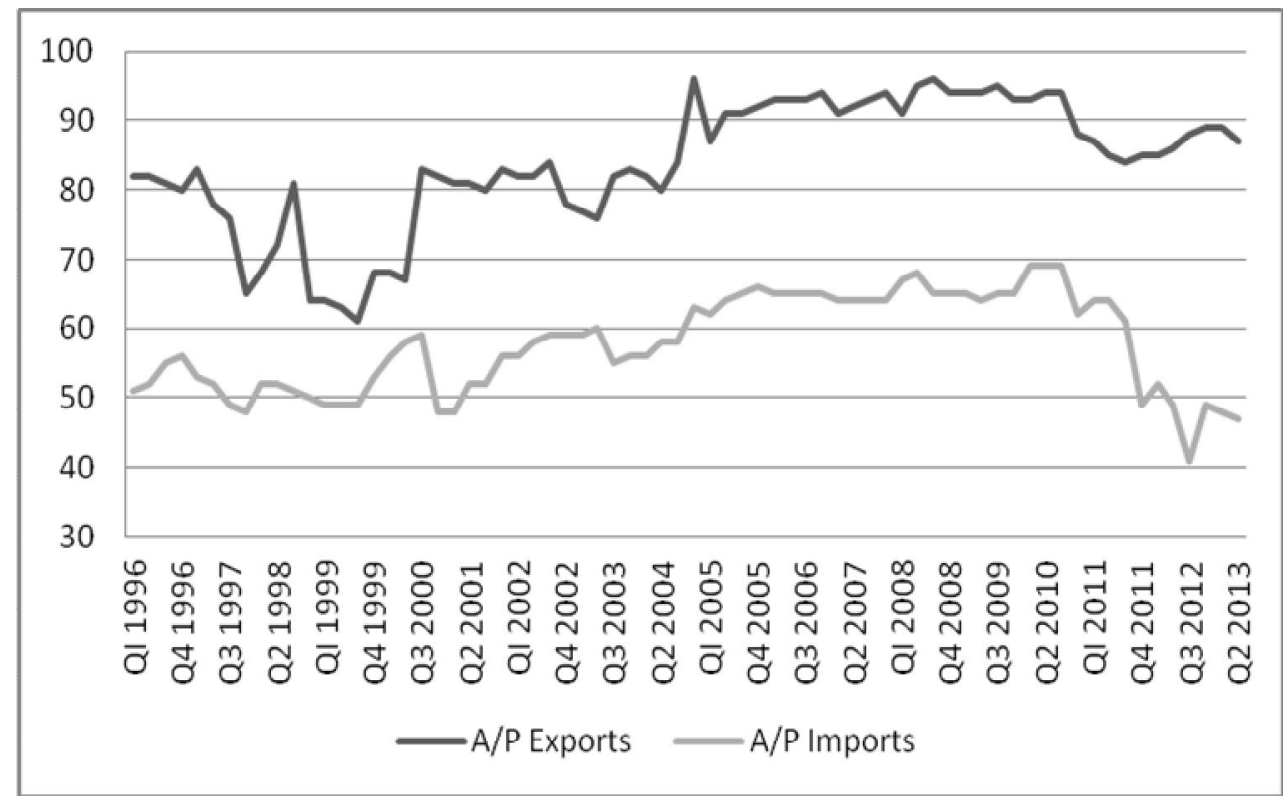

Graph 5: A/P Index for Libya

However, if we take a closer look at the trends in A/P Exports and A/P Imports we clearly observe the presence of three stages in the course of the period: (i) the time period before the implementation of the ZPN policy; (ii) the time period when the ZPN policies has been implemented until the Arab Spring; and (iii) the time period after the Arab Spring. 


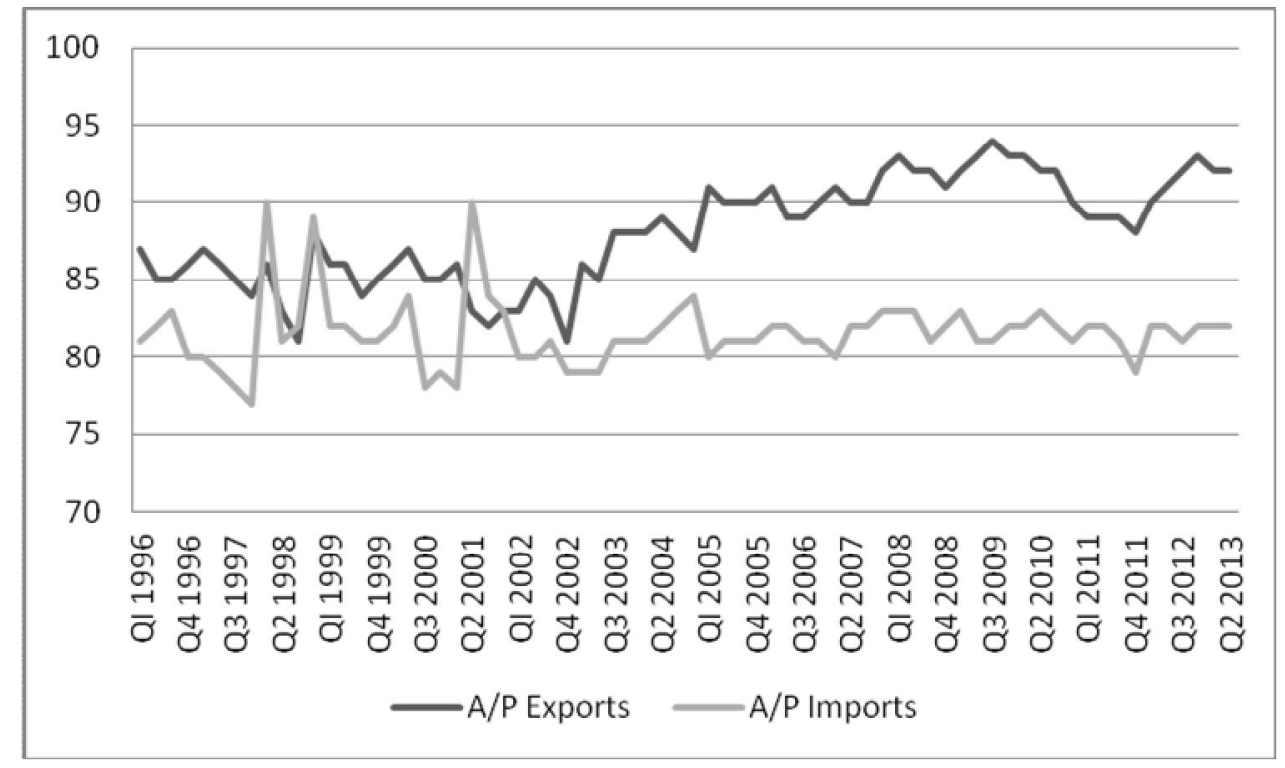

Graph 6: A/P Index for Tunisia

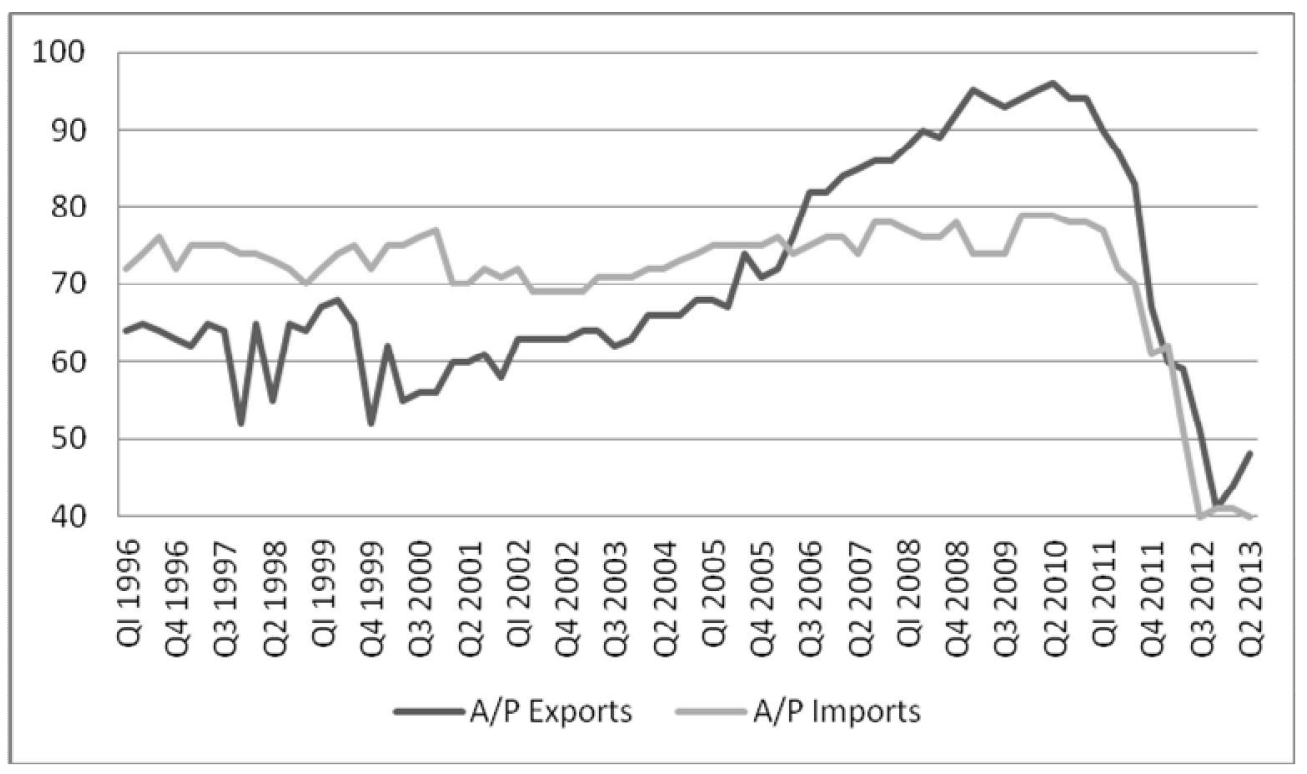

Graph 6: A/P Index for Syria

Explicitly Turkey has realized its export potential in the second period more than in the first period. A/P Export index in the second period rose by \%6-22 (the minimum for Tunisia and the maximum for Syria) compared with that in the fist period while A/P Import index rose by \%2-9 (the minimum for Tunisia and the maximum for Egypt) between the same periods. 
During the quarters when uprising has manifested its effects, the potential realization index decreased. But the degree of decrease in the index varies from one country to another: the fall in the A/P Indexes of Syria and Libya is sharp and deep while it is soft and smooth in the A/P indexes of Egypt and Tunisia.

\section{Conclusions}

Both the "zero problems with neighbours" policy, implemented since 2002, and market diversifications have a positive impact on Turkish export market so as to expand it in the Arab world. But Arab countries have not taken sufficient share from the expansion of Trade market yet. The rise in Arab countries' export share in the total exports of Turkey is six times bigger than the rise in Arab countries' import share in the total imports of Turkey. Besides, although the EU is still the major trade partner of Turkey the trade market diversification policy decreased the share of the EU while increasing the share of Arab countries.

Nevertheless, so called "Arab Spring" movements constituted a resistance to the trade expansion trend. Event though it has a short time period since the beginning it has manifested its effects on the trade flows. Focusing my analysis on the Spring countries I tested through a gravity based model first whether the ZPN policy contributed to the trade expansion, second whether the Arab Spring has impact on Turkey's trade market. On average the ZPN policy has increased Turkish exports to the Spring countries by $\% 13$ and the imports from them by $\% 2$. And on average the Arab Spring has decreased Turkish exports by $\% 4$ and the imports $\% 6$.

On the other hand, during the time period of the implemented ZPN policy Turkey has realized its potential trade with the Spring countries more, compared with the pre-ZPN period. Neither exports nor imports have reached at their natural levels until now. Thus, one can say that there is still a room for countries. However, since the realization of the potential exports is larger than the realization of the potential imports the potential of exporting to Turkey is larger that the potential of exporting to the Spring countries.

After the uprising movements started the trade potential realization ratios sharply decreased. Nevertheless, if we consider the weight of four Spring countries on the Turkish trade market (\%2 of total trade and $\% 4$ of total exports) the probable negative impact of the Arab Spring can be expected to be limited.

However, what is the real risk for Turkey is the contagion of spring movements. Uncertainties prevailing over the Spring countries and concerns about contagion of uprising movements toward other partner countries lead us to expect the negative impacts of the Arab Spring on Turkey's trade market to continue longer.

\section{References}

Al-Atrash, H. and Yousef, T. (2000), Intra-Arab trade: Is it too little?, IMF Working Paper, WP/00/10.

Anderson, J.E. and E. van Wincoop (2001). Gravity with gravitas: A solution to the border puzzle, National Bureau of Economics Research, Paper no. 8079, and reprinted in American Economic Review 93(1) (mars 2003): 170-192. 
Bauer, M. and Schiller, T. (2012), "The Arab Spring in 2012, Center for Applied Policy Research, No:1, January, 2012.

Breisinger, C., Ecker, O., Al-Riffai, P. (2011), Economics of the Arab awakening: from revolution to transformation and food security, IFPRI Policy Briesf 18, May 2011.

Brun, J., C. Carrere, P. Guillaumont and J. de Melo (2002), Has distance died? Evidence from a panel gravity model, unpublished manuscript, University of d'Auvergne.

Davutoğlu, Ahmet (2001), Stratejik Derinlik: Türkiye'nin Uluslararası Konumu, Publisher: Küre, Istanbul.

De Grauwe, P. and F. Skudelny (2000), The Impact of EMU on Trade Flows, Review of World Economics, Welwirtschafliches Archiv, Volume 136, Issue 3, pp. 381-402.

Frankel J. (1997), Regional Trading Blocs in the World Economic System, Institute for International Economics, Washington D.C.

Ghoneim, A.F. (2003), Rules of origin and trade diversion: The case of the Egyptian European partnership agreement, Journal of World Trade, 37 (3) (2003), pp. 597-622

Hakimian, H. (2011), The economic Prospect of the 'Arab Spring': ABumpy Road Ahead, CDPR, No:63, June 2011.

Harrigan, J. (1993), OECD imports and trade barriers in 1983, Journal of International Economics, Vol. 35(1-2), 91111.

Hummels, D. (2001a), Time as a trade barrier, Polycopié, Purdue University, Lafayette.

Hummels, D. (2001b), Toward a geography of trade cost, Polycopié, Purdue University, Lafayette.

Limao, N. and A. J. Venables (2001), Geographical disadvantage: a Heckscher-Ohlin-von Thunen model of international specialization, Journal of International Economics, vol. 58(2), 239-263.

Malik A. and Awadallh, B. (2011), The economics of the Arab Spring, CSAE Working Paper WPS/2011-23.

McCallum, J. (1995), National borders matters: Canada-US regional trade patterns, The American Economic Review, vol. 85. No. 3, 615-623.

McQueen, M. (2002), The EU's free trade agreements with developing countries: a case of wishful thinking?, The World Economy, 16 (9) (2002), pp. 1369-1385

McQueen, J. F. And Wignaraja M.. G. (2005), The Impact of Regional Trade Agreements and Trade Facilitation in the Middle East and North Africa Region, World Bank Policy Research Working Paper No. 3837 , http://papers.ssrn.com/sol3/papers.cfm?abstract_id=922963

Nugent, J. $\quad$ B. (2002), Why Does MENA Trade So Little?, http://siteresources.worldbank.org/INTMNAREGTOPTRADE/Resources/Nugent.pdf

Nugent, J. B.; Yousef, T. M. (2005), Does MENA Defy Gravity? How MENA has Performed in its Intraregional, EU and Other Trade: Implications for EU and Intra-MENA Trade Arrangements, http://www.eui.eu/RSCAS/WPTexts/05_26.pdf

Redding, S. and A.J. Venables (2004), Geography and export performance: External market access and internal supply capacity, in Challenges to Globalization: Analyzing the Economics. CEPR-NBER conference volume. Edited by Baldwin, R.; Winters, L. A. NBER and Chicago University Press, 2004, pp. 95-130. 
E Sorhun /International Journal of Research in Business and Social Sciences Vol 2, No 4, 2013. ISSN: 2147-4478

Tinbergen, J. (1962), Shaping the World Economy, Twentieth Century Fund, New York.

Turkish Statistical Institute (2013), Statistical Data, Ankara, Turkey 